\title{
Lidocaine suppresses the malignant behavior of gastric cancer cells via the c-Met/c-Src pathway
}

\author{
WEI ZENG, ZE TING XING, MEI YUN TAN, YAN WEN WU and CHUN YUAN ZHANG \\ Department of Anesthesiology, Affiliated Boai Hospital of Zhongshan, Southern Medical University, \\ Zhongshan, Guangdong 528403, P.R. China
}

Received September 30, 2020; Accepted December 22, 2020

DOI: $10.3892 /$ etm.2021.9868

\begin{abstract}
The present study was designed to investigate the role and mechanism of action behind the action of lidocaine in gastric cancer cells. Lidocaine was tested for its potential role in affecting the viability of cells using Cell Counting Kit-8 (CCK-8) assays. It was found that there was a decreased MKN45 cell viability upon lidocaine treatment in a dose-dependent manner. Phosphorylated c-Met, phosphorylated c-Src, c-Met and c-Src levels were detected using western blotting following lidocaine or hepatocyte growth factor (HGF) intervention. It was found that the phosphorylation levels of c-Met and c-Src were markedly reduced by lidocaine treatment, with this effect being further relieved by the addition of HGF. Subsequently, whether lidocaine repressed the malignant biological properties of gastric cancer cells through the c-Met/c-Src axis was further investigated through the detection of epithelial-mesenchymal transition markers $(\mathrm{N}$-caderin and vimentin), wound healing and transwell assay analysis. In addition, cell apoptosis and the levels of apoptosis-related proteins were determined using TUNEL and western blot assays, respectively. The results demonstrated that the malignant behavior of cells were notably repressed upon lidocaine treatment, but the addition of HGF markedly reversed these effects, indicating that the effects of lidocaine on supressing the malignant behaviour of cells could be mediated through the c-Met/c-Src axis. Subsequently, whether lidocaine affected the sensitivity of cells to cisplatin or 5-FU was analyzed using a CCK-8 assay. Enhanced sensitivity of cells to cisplatin or 5 -FU was observed when treated in combination with lidocaine. The present study concluded that the involvement of the c-Met/c-Src pathway in the biological behaviour of MKN45 cells was mediated by lidocaine. Therefore, lidocaine may
\end{abstract}

Correspondence to: Dr Chun Yuan Zhang, Department of Anesthesiology, Affiliated Boai Hospital of Zhongshan, Southern Medical University, 6 Chenggui Road, East District, Zhongshan, Guangdong 528403, P.R. China

E-mail: zhangchunyun85@163.com

Key words: lidocaine, gastric cancer, c-Met, c-Src, proliferation, epithelial-mesenchymal transition have the potential to suppress the malignant behaviour and proliferation of gastric cancer cells.

\section{Introduction}

Gastric cancer is the fifth most common cancer worldwide (1). Surgical treatment is the first choice for gastric cancer; however, the 5-year survival rate is only $20-30 \%$ due to low early diagnosis rates and high postoperative recurrence and metastasis rates (2).

Lidocaine is a local anesthetic which can effectively inhibit the biological activity of a variety of cancer types. In vivo and in vitro studies have indicated the antitumor effects of lidocaine in gastric cancer (3-5). Mechanistically, lidocaine has been found to decrease Src activation (6-8). A recent study suggested that lidocaine can inhibit the proliferative and invasive capabilities of c-Met positive MKN45 cells (3). c-Met is a member of the protein tyrosine kinase receptor superfamily, which is encoded by the mesenchymal-epithelial transition (MET) proto-oncogene and mainly produced by epithelial cells (9). c-Met expression in gastric cancer tissues is higher compared with that in healthy tissues and is associated with invasion, metastasis and poor prognosis of gastric cancer, but is not associated with sex, age, size, location or differentiation degree of the tumor (10-12). MET amplification has been found to be common feature in gastric cancer and its inhibition contributes to apoptosis of gastric cancer cells (13-16). c-Src, a non-receptor tyrosine kinase, is closely associated with the proliferation and survival of cancer cells $(17,18)$. Hepatocyte growth factor (HGF) functions as a natural endogenous ligand of the MET receptor, which forms a signaling pathway with c-Met, which is closely related to the occurrence, development, metastasis and prognosis of gastric cancer $(9,19,20)$. In most types of gastric cancer, the inhibition of this signaling pathway exerts an antiproliferative effect and induces apoptosis in gastric cancer cells (13). c-Met/c-Src signaling has been reported to play a vital role on the growth of MET-activated gastric cancer cells (13). Although the potential anti-tumor effects of lidocaine have been reported, the role and mechanism of action of lidocaine remain unclear. The present study aimed to investigate the efficacy of lidocaine against the malignant behavior and proliferation of gastric cancer cells and its mechanism of action. 


\section{Materials and methods}

Cell culture. Human gastric carcinoma cells MKN45 (ATCC), a c-MET-positive cell line, were cultured in RPMI-1640 medium (Thermo Fisher Scientific, Inc.) containing $10 \% \mathrm{FBS}$ at $37^{\circ} \mathrm{C}$ after resuscitation until adherent. Once the cell density reached $80 \%$, cells were digested with $0.25 \%$ trypsin and passaged at a 1:3 ratio of cells: Medium. MKN45 cells were continuously cultured using the same conditions for subsequent experiments.

Cell Counting Kit-8 (CCK-8) assay. MKN45 cells were cultured to the logarithmic stage and seeded into 96-well plates $\left(2 \times 10^{3}\right.$ cells/well). After overnight culture, the culture solution was discarded. Media containing lidocaine (Selleck Chemicals) at final concentrations of 1,5 and $10 \mathrm{mM}$ was added to the cells for incubation for $48 \mathrm{~h}$ at $37^{\circ} \mathrm{C}$. Each lidocaine concentration treatment was performed as five separate assays. In analyzing the influence of lidocaine on the sensitivities of cells for cisplatin (cat. no. A10221; Adooq Bioscience) or 5-FU (cat. no. CSN19496, CSNpharm, Inc.), cells were cultured in RPMI-1640 medium containing cisplatin $(0.25$ or $0.5 \mu \mathrm{g} / \mathrm{ml})$ or in combination with lidocaine $(10 \mathrm{mM})$ or $\mathrm{HGF}(40 \mathrm{ng} / \mathrm{ml}$, cat. no. AP3513; Adooq Bioscience). Following culture for $48 \mathrm{~h}, 10 \mu \mathrm{l} \mathrm{CCK}-8$ solution was added for incubation for $2 \mathrm{~h}$ at $37^{\circ} \mathrm{C}$ (Abcam). The absorbance at a wavelength of $450 \mathrm{~nm}$ was detected using a microplate reader.

Western blotting. Total protein was extracted from MKN45 cells using RIPA lysis buffer (Beijing Solarbio Science \& Technology Co., Ltd.). Protein concentration was determined using a BCA kit. A total of $30 \mu \mathrm{g}$ protein was obtained, mixed with loading buffer and loaded into $10 \%$ polyacrylamide gels. Polyacrylamide gel electrophoresis was performed to separate the proteins. The proteins were then transferred to PVDF membranes and 5\% skimmed milk was used to block the membranes at room temperature for $1 \mathrm{~h}$. Subsequently, the membranes were incubated with primary antibodies [c-Met, cat. no. ab216574, 1:1,000; phosphorylated (p)-c-Met, cat.no.ab5662, 1:1,000; c-Src,cat.no.ab16885, 1:1,000;p-c-Src, cat. no. ab40660, 1:2,000; N-cadherin, cat. no. ab76011, 1:5,000; vimentin, cat. no. ab92547, 1:2,000; GAPDH, ab8245, 1:10,000; all from Abcam] at $4{ }^{\circ} \mathrm{C}$ overnight and secondary antibodies [horseradish peroxidase (HRP)-conjugated rabbit anti-mouse, cat. no. ab47827, 1:10,000; HRP-conjugated goat anti-Rabbit IgG, ab97040, 1:10,000; Abcam] at room temperature for $1 \mathrm{~h}$. Protein bands were visualized using a gel imaging system (Bio-Rad Laboratories, Inc.) following addition of ECL developing reagent (Beyotime Institute of Biotechnology). The gray value of protein bands was analyzed using Image $\mathbf{J}$ software 1.46r (National Institutes of Health). The grayscale ratio of target proteins to GADPH was then calculated.

Wound healing assay. MKN45 cells were seeded into 6-well plates $\left(2 \times 10^{6}\right.$ cells/well $)$ and cultured for $24 \mathrm{~h}$. When cell confluence reached $100 \%$, linear scratches were made using a 200- $\mu 1$ sterile pipette tip and photographed as the controls. After being washed with PBS, the cells were treated with serum-free medium containing lidocaine $(10 \mathrm{mM})$ or HGF (40 ng/ml) at $37^{\circ} \mathrm{C}$ for $48 \mathrm{~h}$. Images were then captured using a light microscope (magnification, x200; Olympus Corporation). The migration rate was calculated using the formula: Migration rate $=(\mathrm{T} 0 \mathrm{~h}$ area-T48 $\mathrm{h}$ area $) / \mathrm{T} 0 \mathrm{~h}$ area $\times 100 \%$.

Transwell assay. The invasive capabilities of MKN45 cells were detected using Transwell assays. Matrigel $(50 \mathrm{mg} / \mathrm{l})$ was added to the upper chamber of the Transwell at $4^{\circ} \mathrm{C}$ to dry for $5 \mathrm{~h}(0.4 \mu \mathrm{M}$ pore size; BD Biosciences). Once the cells were digested and collected, the cell suspension $\left(5 \times 10^{4}\right.$ cells $\left./ 200 \mu \mathrm{l}\right)$ was prepared using RPMI-1640 medium containing no FBS and seeded into the Transwell upper chamber. Medium containing $10 \%$ FBS was added into the lower chamber. After $48 \mathrm{~h}$ at $37^{\circ} \mathrm{C}$, the chamber was removed and cells in the upper chamber were wiped off using a cotton swab. The cells were fixed with $4 \%$ paraformaldehyde for $15 \mathrm{~min}$ at room temperature and then stained with $0.1 \%$ crystal violet for $30 \mathrm{~min}$ at room temperature (Sigma Aldrich; Merck KGaA) and observed under a light microscope (magnification x200).

TUNEL assay. Following treatment of MKN45 cells, cells ( $1 \times 10^{6}$ cells) were collected added to polylysine slides and fixed using $4 \%$ paraformaldehyde for $25 \mathrm{~min}$ at room temperature. Subsequently, $0.2 \%$ Triton X-100 was added to the sections and incubated for $5 \mathrm{~min}$ at room temperature. Apoptotic cells were stained with TUNEL reagent $(50 \mu \mathrm{l})$ for $1 \mathrm{~h}$ at room temperature and DAPI for $10 \mathrm{~min}(0.4 \mu \mathrm{g} / \mathrm{ml}$, blue $)$ in the dark, according to the instructions of the TUNEL Fluorescence Assay kit (Roche Diagnostics). Apoptosis was observed under a fluorescence microscope (Roche Diagnostics). In total, five non-overlapping fields were randomly selected. The apoptosis levels of the cells were calculated using the following method: (The number of positive cells in each field/the total number of all cells in the field) $\mathrm{x} 100 \%$.

Statistical analysis. Data are presented as the mean \pm SD. Experimental data among the various groups were compared using one-way ANOVAs followed by post hoc Tukey's tests using GraphPad 7.0 (GraphPad Software, Inc.). Each experiment was repeated at least three times.

\section{Results}

Effects of lidocaine on the c-Met/c-Src axis in MKN45 cells. To evaluate the effects of lidocaine on cell growth, MKN45 cells were exposed to various concentrations of lidocaine for $48 \mathrm{~h}$ and the cell viability was measured. Various concentrations of lidocaine were found to inhibit MKN45 cell proliferation in a dose-dependent manner (Fig. 1A), indicating that MKN45 cells are sensitive to lidocaine. To further investigate the mechanism of action of lidocaine, western blot assays were performed to analyze the protein expression and phosphorylation levels of c-Met and c-Src. Although there were no marked changes in the expression levels of c-Met and c-Src in MKN45 cells upon treatment with various concentrations of lidocaine, a significant decrease was observed in the phosphorylation levels of c-Met and c-Src (Fig. 1B and C).

HGF suppresses the efficacy of lidocaine in MKN45 cells via the $c$-Met/c-Src axis. The aforementioned findings indicated that there was an inhibitory effect of lidocaine on c-Met and 

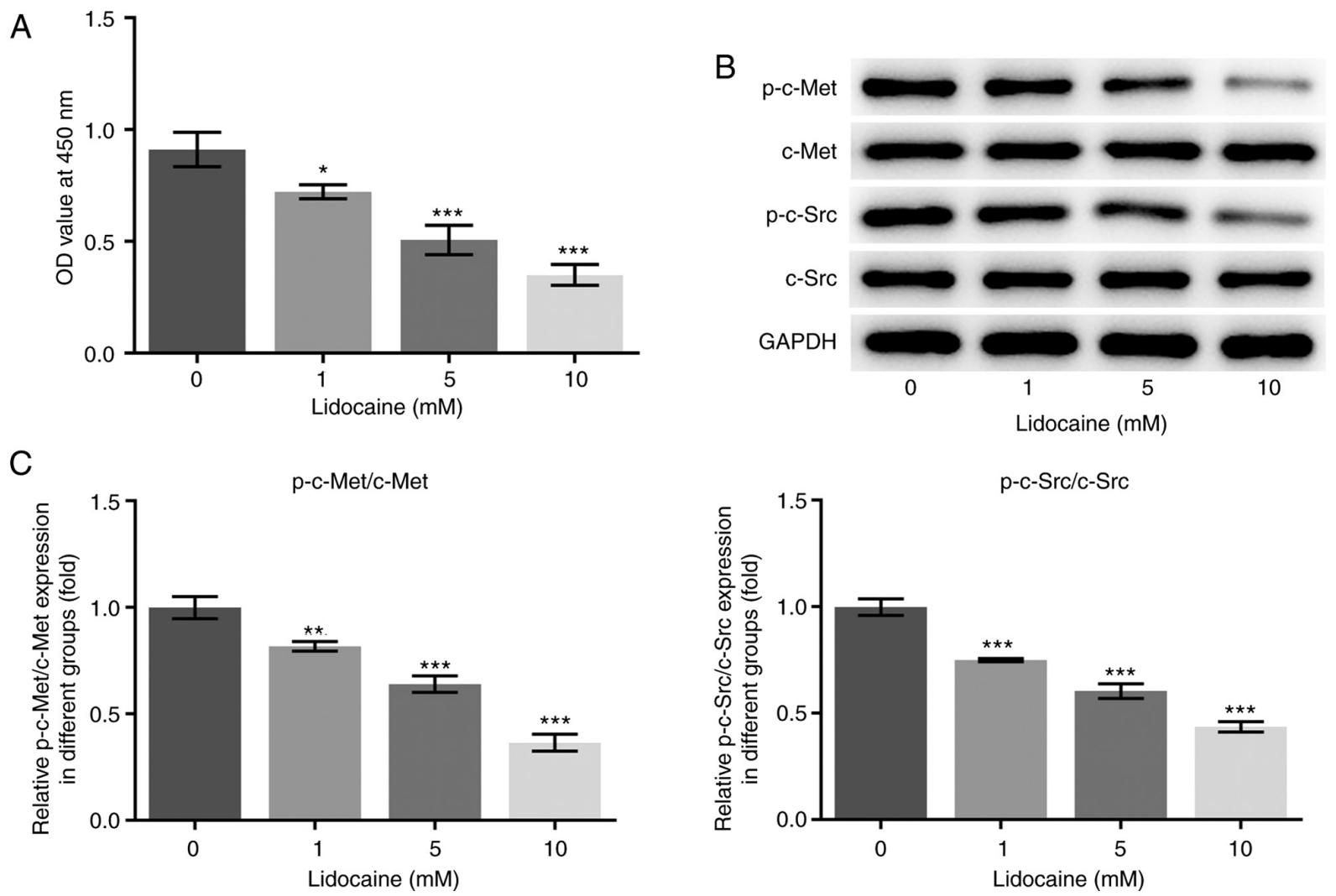

Figure 1. Lidocaine reduces the phosphorylation levels of c-Met and c-Src. (A) MKN45 cells were incubated in medium with or without lidocaine (1,5 and $10 \mathrm{mM}$ ) and the cell viability was detected. (B) MKN45 cell lysates were used to detect the expression of c-Met, c-Src, p-c-Met and p-c-Src. (C) The ratios of p-c-Met/c-Met and p-c-Src/c-Src were calculated. Data are expressed as the mean $\pm \mathrm{SD} .{ }^{*} \mathrm{P}<0.05,{ }^{* *} \mathrm{P}<0.01$ and ${ }^{* * * *} \mathrm{P}<0.001$ vs. $0 \mathrm{mM}$ lidocaine treated cells. OD, optical density; p-, phosphorylated.

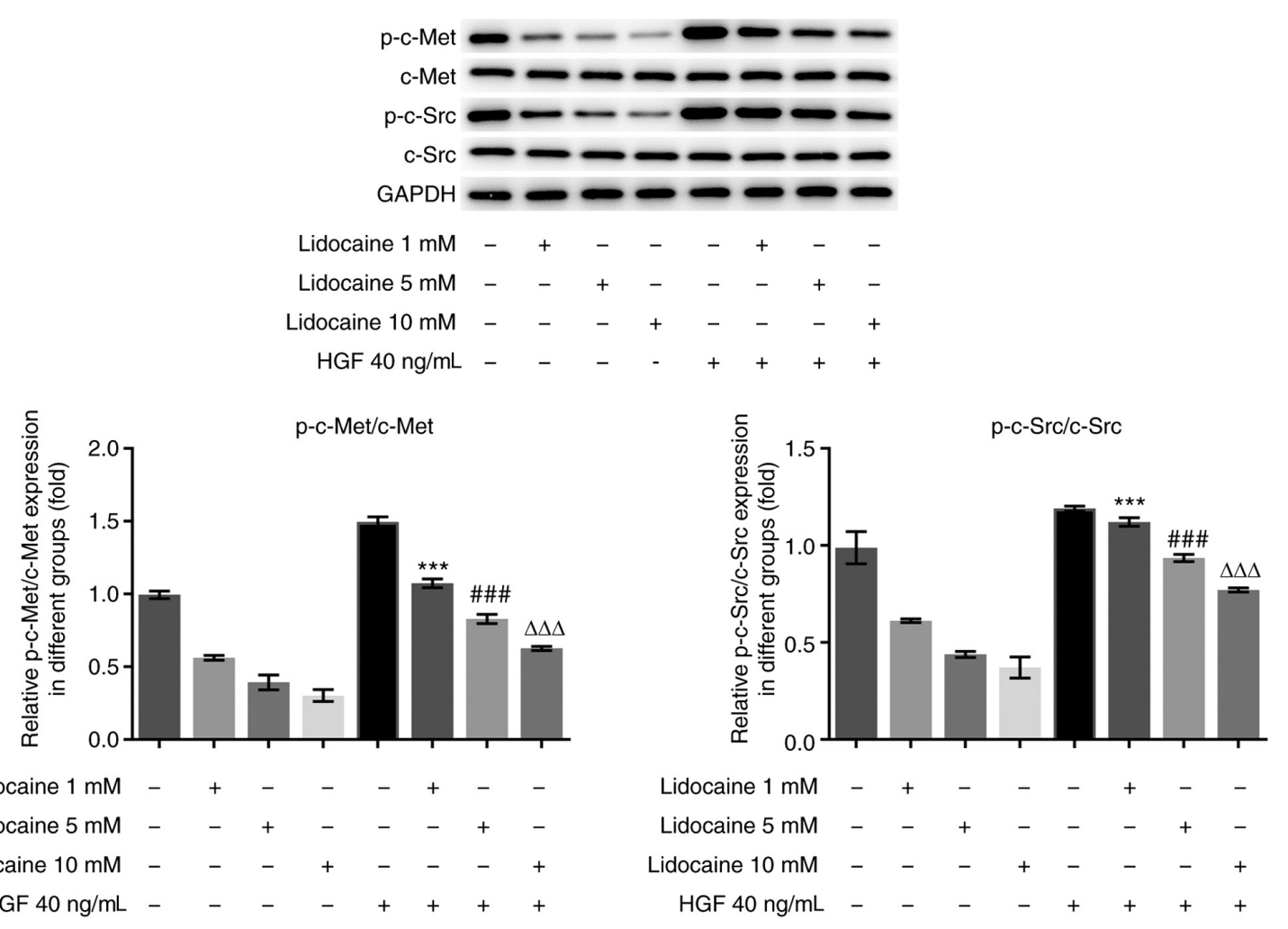

Figure 2. HGF treatment reverses the effects of lidocaine in c-Met $/ \mathrm{c}-\mathrm{Src}$ activation. HGF ( $40 \mathrm{ng} / \mathrm{ml})$ inhibited the effects of lidocaine in suppressing c-Met/c-Src signaling. The bar graphs were drawn using the mean $\pm \mathrm{SD}$ of relative protein expression levels. ${ }^{* * * *} \mathrm{P}<0.001 \mathrm{vs} .1 \mathrm{mM}$ lidocaine; ${ }^{\# \# \|} \mathrm{P}<0.001 \mathrm{vs} .5 \mathrm{mM}$ lidocaine; ${ }^{\Delta \Delta \Delta} \mathrm{P}<0.001$ vs. $10 \mathrm{mM}$ lidocaine. HGF, hepatocyte growth factor; $\mathrm{p}$-, phosphorylated. 

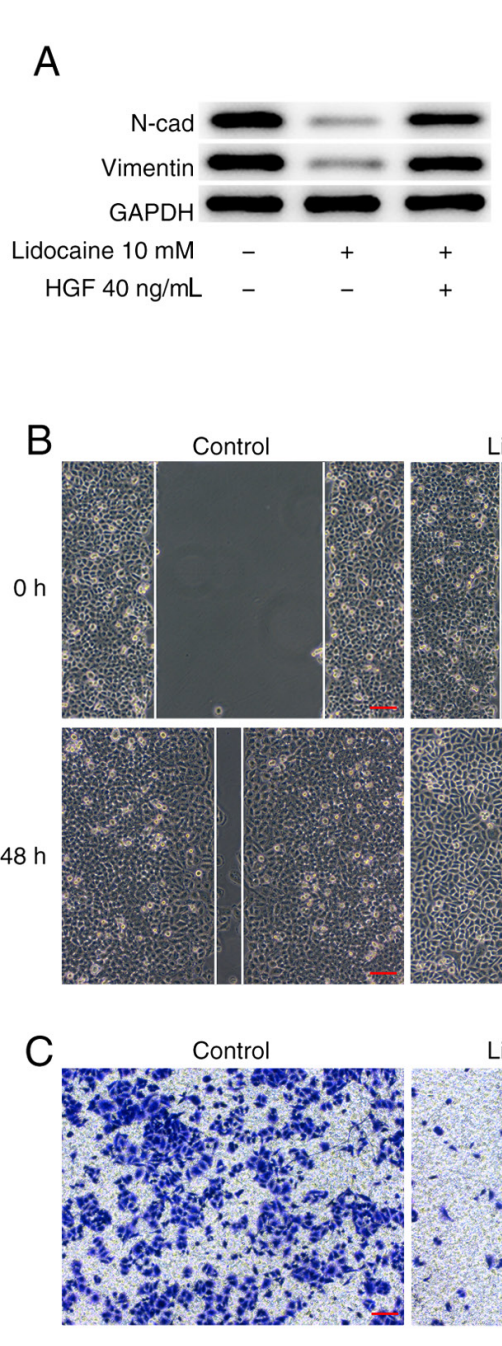
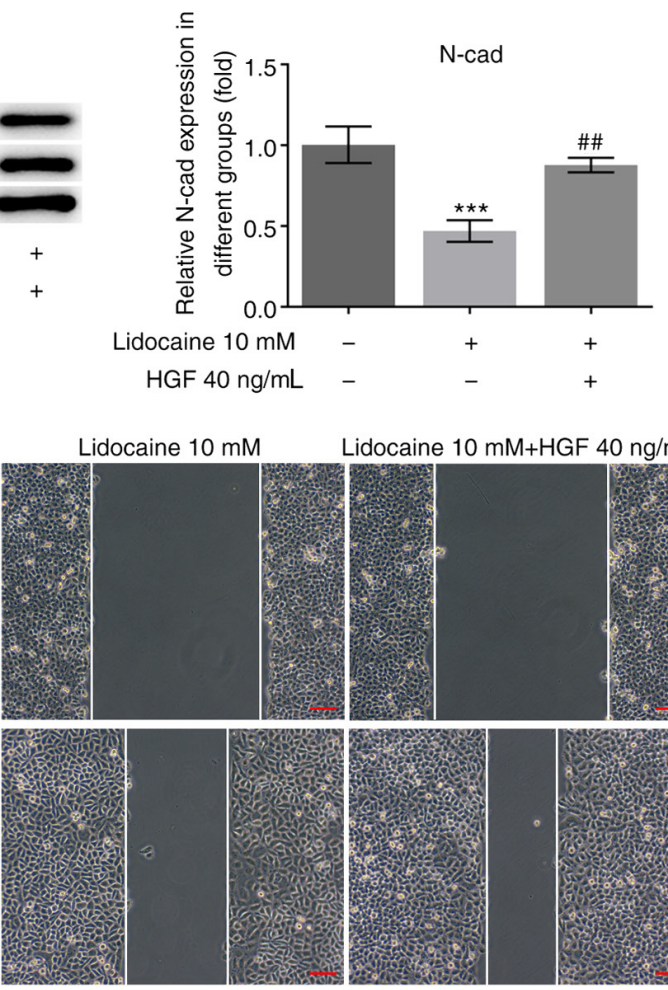

Lidocaine $10 \mathrm{mM}+\mathrm{HGF} 40 \mathrm{ng} / \mathrm{mL}$
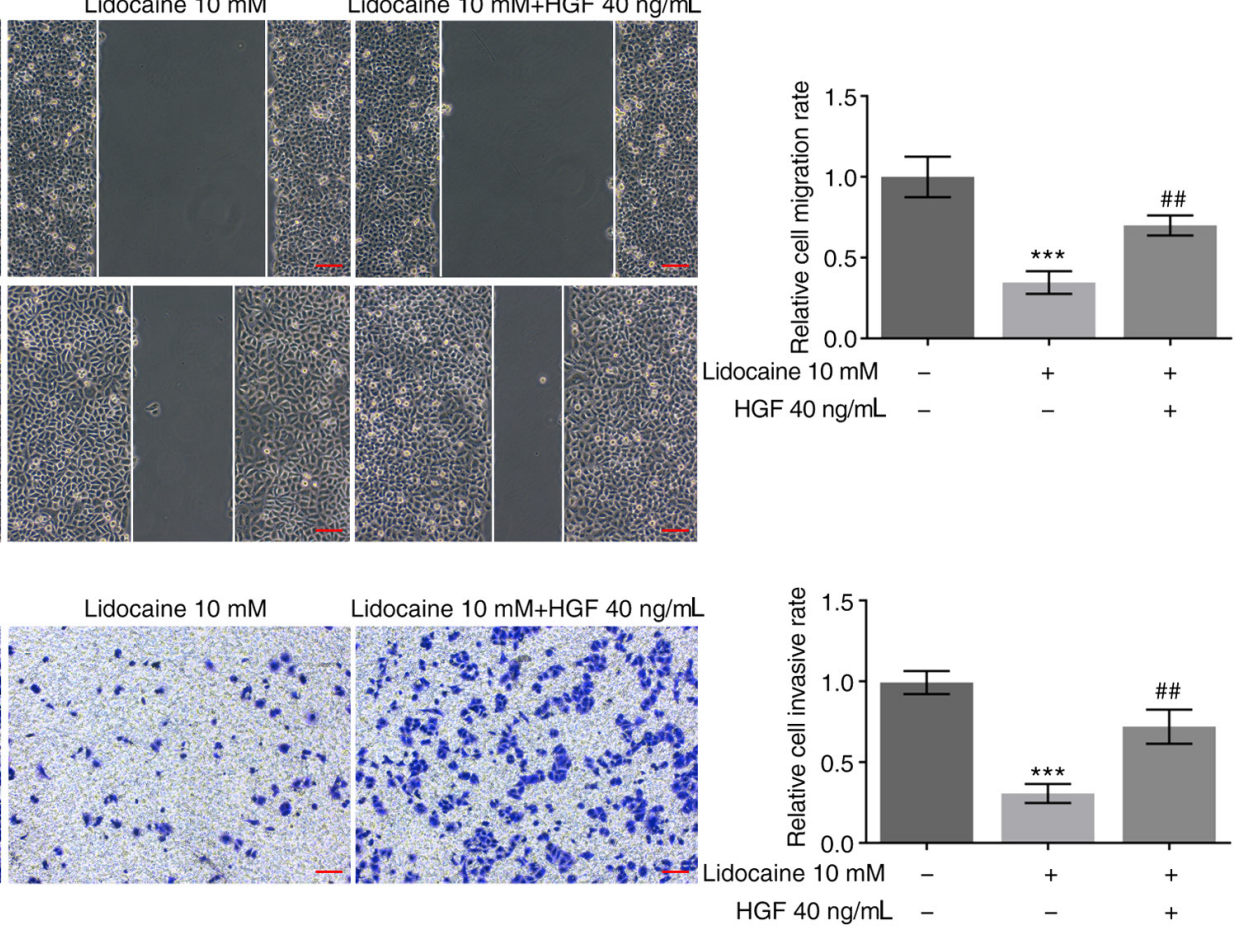

Figure 3. HGF reverses the influences of lidocaine for migration and invasion of MKN15 cells. (A) Detection of epithelial-mesenchymal transition markers, $\mathrm{N}$-cad and vimentin, using western blot assays. (B) Wound healing and (C) Transwell assays were performed to determine the migratory and invasive abilities of MKN45 cells treated with lidocaine. Scale bar, $100 \mu \mathrm{M}$. Data are expressed as the mean $\pm \mathrm{SD}$. ${ }^{* * *} \mathrm{P}<0.001$ vs. the untreated control group; ${ }^{\# \#} \mathrm{P}<0.01$,

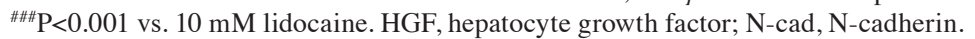

c-Src. It has been reported that c-Met/c-Src activation is closely related to the overall survival rate of patients with gastric cancer and is considered as a potential therapeutic target for gastric cancer (20-24). As such, it was hypothesized that the c-Met/c-Src pathway may mediate the suppressive effects of lidocaine on MKN45 cell proliferation. To validate this hypothesis, MKN45 cells were pre-treated with HGF $(40 \mathrm{ng} / \mathrm{ml})$, followed by treatment with various concentrations of lidocaine $(1,5$ and $10 \mathrm{mM})$ for $48 \mathrm{~h}$ (Fig. 2). HGF is a known activator of c-MET (25). A marked increase in the phosphorylation levels of c-Met and c-Src was observed in MKN45 cells treated with the various concentrations of lidocaine in the presence of HGF, when compared with lidocaine treatment alone. In addition, no marked changes in the expression of c-Met and c-Src were observed in MKN45 cells following lidocaine or HGF treatment.

Lidocaine suppresses the malignant behavior of MKN45 cells. Subsequently, the present study further evaluated the influence of lidocaine on the malignant behavior of MKN45 cells through analyzing the abilities of cell migration and invasion, as well as the expression of EMT-related markers. Western blot assays were performed to analyze the expression of $\mathrm{N}$-cadherin and vimentin, while migration and invasion were investigated using wound healing and Transwell assays. A significant reduction in $\mathrm{N}$-cadherin and vimentin protein expression levels was found in MKN45 cells exposed to lidocaine, while HGF reversed these effects (Fig. 3A). Metastasis is one of the factors that impede successful treatment of patients with gastric cancer. Therefore, in vitro migration and invasion assays were subsequently performed in MKN45 cells following lidocaine or HGF treatment. MKN45 cells exposed to $10 \mathrm{mM}$ lidocaine exhibited significantly higher levels of both migration and invasion, while HGF treatment reversed these effects (Fig. 3B and C).

Lidocaine inhibits the apoptosis of MKN45 cells. Fluorescein-dUTP was used to analyze cell apoptosis using a TUNEL assay. Following treatment of MKN45 cells with lidocaine $(10 \mathrm{mM})$, a marked increase in the number of cells showing green fluorescence was observed, indicating an increase in the extent of cell apoptosis compared with 
A

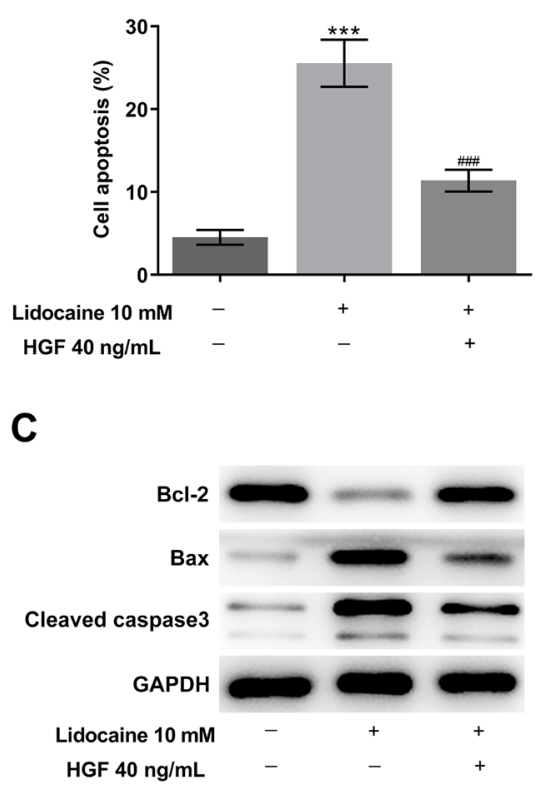

D

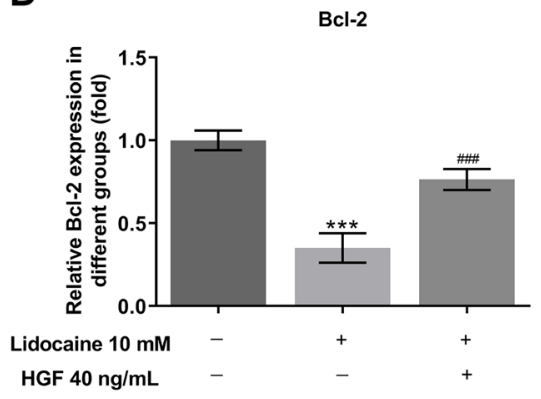

B
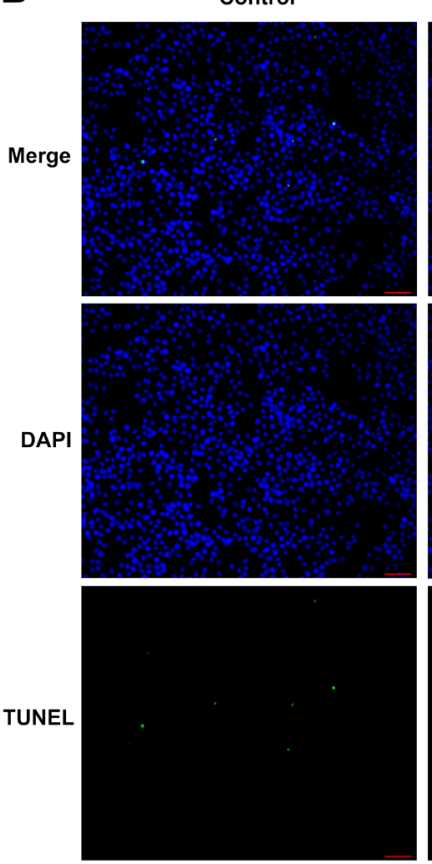

Bax

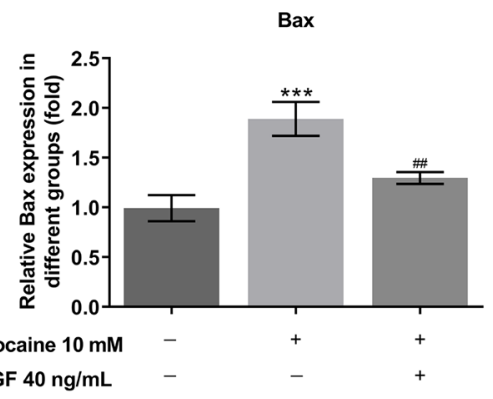

Lidocaine $10 \mathrm{mM}$
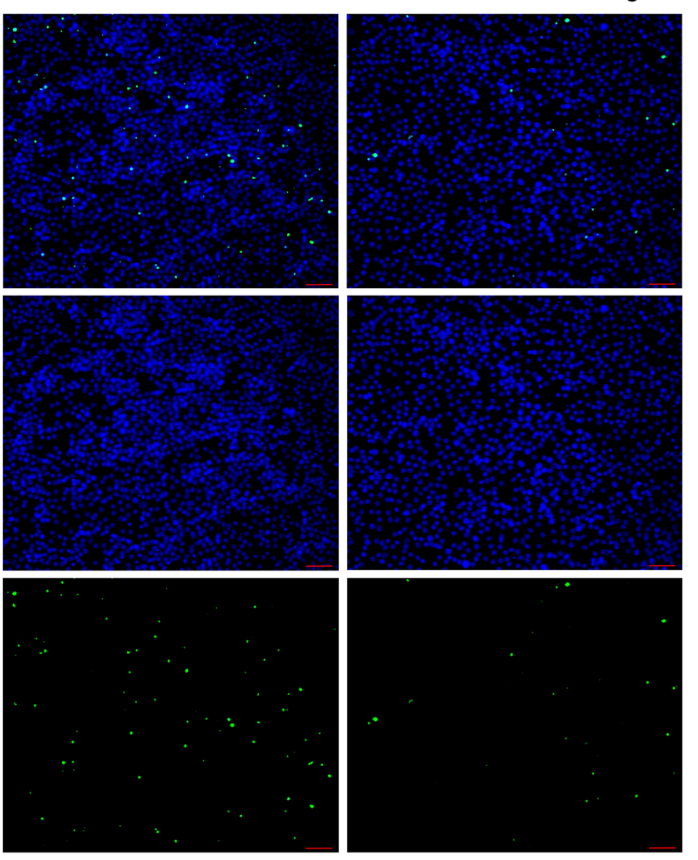

总

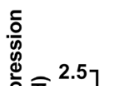

Lidocaine $10 \mathrm{mM}+\mathrm{HGF} 40 \mathrm{ng} / \mathrm{mL}$
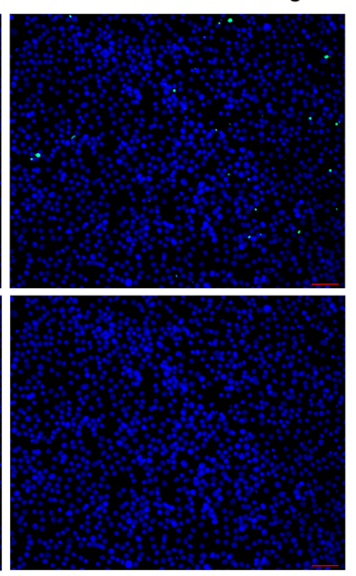

Cleaved caspase 3

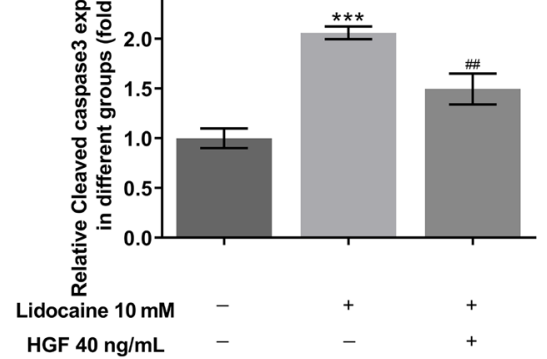

HGF $40 \mathrm{ng} / \mathrm{mL}$

Figure 4. Promoting effects on apoptosis of lidocaine are reversed by HGF co-treatment. (A and B) TUNEL assays were performed to determine the extent of apoptosis of MKN45 cells. (C) The expression levels of apoptosis-related proteins were measured using western blot analysis and (D) quantified, following lidocaine $(10 \mathrm{mM})$ or $\mathrm{HGF}(40 \mathrm{ng} / \mathrm{ml})$ treatment. Scale bar, $100 \mu \mathrm{M}$. Data are expressed as the mean $\pm \mathrm{SD}$ of three independent experiments. ${ }^{* * *} \mathrm{P}<0.001 \mathrm{vs}$. the control group; ${ }^{\# \#} \mathrm{P}<0.01,{ }^{\# \# \#} \mathrm{P}<0.001$ vs. $10 \mathrm{mM}$ lidocaine $10 \mathrm{mM}$. HGF, hepatocyte growth factor.
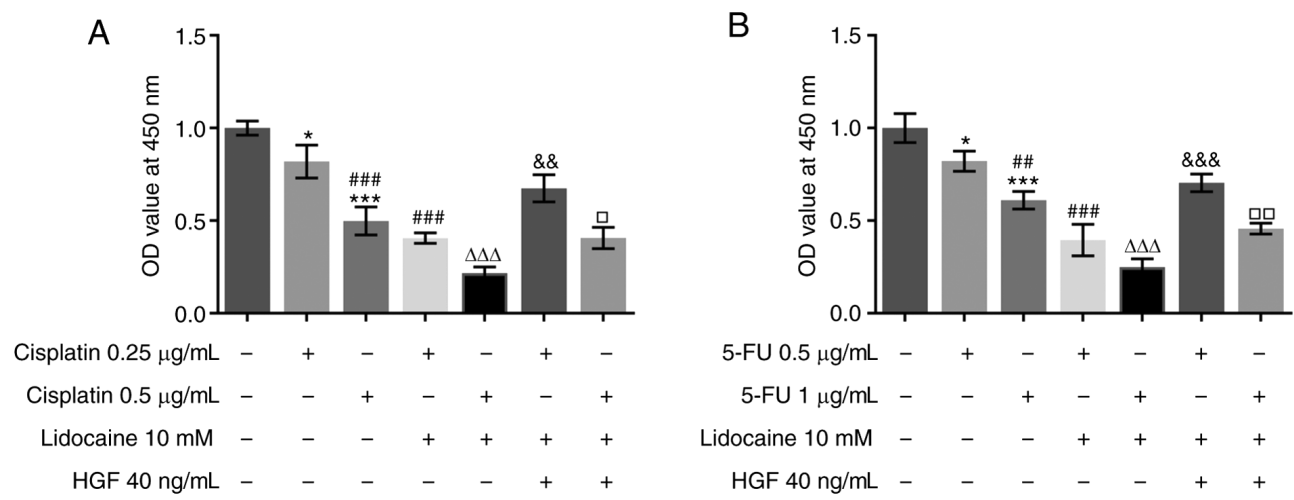

Figure 5. HGF is implicated in the enhanced sensitivity of MKN45 cell to cisplatin or 5-FU caused by lidocaine. (A) The synergistic effects of lidocaine and cisplatin on MKN45 cell viability. ${ }^{*} \mathrm{P}<0.05,{ }^{* * * *} \mathrm{P}<0.001$ vs. the control group; ${ }^{\# \# t} \mathrm{P}<0.001$ vs. $0.25 \mu \mathrm{g} / \mathrm{ml}$ cisplatin; ${ }^{\Delta \Delta \Delta} \mathrm{P}<0.001 \mathrm{vs} .0 .5 \mu \mathrm{g} / \mathrm{ml}$ cisplatin; \&\& $\mathrm{P}<0.01$ vs. $0.25 \mu \mathrm{g} / \mathrm{ml}$ cisplatin $+10 \mathrm{mM}$ lidocaine; ${ }^{\mathrm{P}}<0.05 \mathrm{Vs} 0.5 \mu \mathrm{g} / \mathrm{ml}$ cisplatin $+10 \mathrm{mM}$ lidocaine. (B) The synergistic effects of lidocaine and 5-FU on MKN45 cell viability. $\mathrm{P}<0.05,{ }^{* * *} \mathrm{P}<0.001$ vs. the control group; ${ }^{\# \#} \mathrm{P}<0.01,{ }^{\# \# \#} \mathrm{P}<0.001$ vs. $0.5 \mu \mathrm{g} / \mathrm{ml} 5-\mathrm{FU} ;{ }^{\Delta \Delta \Delta}{ }^{\mathrm{P}}<0.001 \mathrm{vs} .1 \mu \mathrm{g} / \mathrm{ml} 5-\mathrm{FU}$; \&\&\& $\mathrm{P}<0.001 \mathrm{vs} .0 .5 \mu \mathrm{g} / \mathrm{ml} 5-\mathrm{FU}$ $+10 \mathrm{mM}$ lidocaine; ${ }^{\square} \mathrm{P}<0.01 \mathrm{vs} .1 \mu \mathrm{g} / \mathrm{ml}$ 5-FU + $10 \mathrm{mM}$ lidocaine. 5-FU, 5-fluorouracil; HGF, hepatocyte growth factor; OD, optical density .. 
(Fig. 4A and B). The expression of apoptosis-related proteins (Bcl-2, Bax and cleaved caspase 3) in MKN45 cells was detected using western blot assays. Significant changes in all of the aforementioned protein expression levels in cells exposed to lidocaine were found compared with the control group (Fig. 4C and D). The expression levels of the pro-apoptotic protein $\mathrm{Bcl}-2$ were significantly decreased, whilst Bax and cleaved caspase 3 expression was significantly increased. The results indicated that lidocaine induced cell apoptosis by potentially activating the intrinsic c-Met/c-Src pathway.

Lidocaine enhances the sensitivity of cells to chemotherapy. The resistance of tumor cells to chemotherapy drugs limits the efficacy of drugs and is a major obstacle to effective cancer chemotherapy (26). The sensitivity of MKN45 cells exposed to lidocaine in combination with cisplatin to chemotherapy was assessed using a CCK-8 assay. Cisplatin inhibited cell viability in a dose-dependent manner, the effects of which were significantly enhanced when combined with lidocaine treatment (Fig. 5A). The synergistic inhibitory effects of lidocaine were also observed in MKN45 cells treated with 5-FU (Fig. 5B). Moreover, the promoting effects of HGF on cell viability were observed in cells treated with lidocaine, cisplatin when compared with co-treatment of cisplatin and lidocaine. Similarly, the effects of the combination treatment of 5-FU and lidocaine on cell viability were reversed by HGF.

\section{Discussion}

Lidocaine is a local anesthetic, with strong and lasting effects and good surface penetration (27). Intravenous lidocaine injections may effectively relieve pain and reduce fentanyl consumption during the early postoperative period (28). Recent studies have demonstrated a possible regulatory mechanism of action for lidocaine through suppressing the proliferation of gastric cancer cells, which is associated with ERK1/2 phosphorylation, the MAPK pathway and altering the expression profiles of microRNAs (3-5). EMT activation is involved in the cell invasion and metastasis of a variety of cancer types $(29,30)$. In the present study, lidocaine downregulated the expression levels of the EMT markers, N-cadherin and vimentin, the effects of which were inhibited by HGF treatment. The $\mathrm{HGF} / \mathrm{c}-\mathrm{Met}$ pathway has previously been found to induce EMT in gastric cancer cells (31). Based on these experimental data, lidocaine may suppress the EMT process by inhibiting the activation of the c-Met/c-Src signaling pathway.

The proliferative and anti-apoptotic functions of HGF have been previously confirmed in gastric cancer cells, consistent with the results of the present study (32). Abnormal HGF levels and apoptosis dysregulation are closely associated with the pathogenesis of gastric cancer (33). Detection of growth factors and apoptosis-related proteins has revealed an increased HGF expression and dysregulated $\mathrm{Bax} / \mathrm{Bcl}-2$ in patients with gastric cancer (34). The present study found that lidocaine decreased Bcl-2 levels and increased the levels of Bax and cleaved caspase 3 through the c-Met/c-Src pathway, and also revealed that lidocaine may promote mitochondrial mediated apoptosis pathway to induce cell apoptosis. Similar roles for lidocaine in apoptosis have also been reported a number of malignancies, including lymphoma, colorectal cancer and cervical cancer (35-37). The present study demonstrated that promoting apoptosis through lidocaine treatment resulted in the inhibition of cell proliferation, indicating the potential anti-tumor effects of lidocaine on gastric cancer cells.

HGF was shown to suppress the effects of lidocaine in MKN45 cells. HGF is cytotoxic and serves as a ligand for c-Met (38). HGF/c-Met signaling plays a vital role in normal biological functions as well as cancer pathology, where it has been implicated in tumor metastasis $(23,39)$. Inhibition of this pathway may sensitize tumor cells to chemotherapy (24). It has previously been shown that c-MET-mediates the malignant behaviors in NT2D1 non-seminoma cells, as well as being implicated in the recruitment of c-Src, which has been associated with the aggressiveness of some types of cancer (40). In the present study, lidocaine alone markedly suppressed cell proliferation, while its combination with cisplatin resulted in the synergistic suppression of cell proliferation. Furthermore, HGF treatment reversed these effects, indicating that the inhibition of c-Met/c-Src with lidocaine enhanced the anti-proliferative effects of cisplatin.

Taken together, the findings of the present study provided evidence supporting a potential role of lidocaine against the malignant behavior of gastric cancer cells and provided a novel insight into the mechanisms of action of lidocaine in gastric cancer.

\section{Acknowledgements}

No applicable.

\section{Funding}

The present study was supported by the Pharmaceutical Research Fund of Guangdong Province Hospital (approval no. 2020XC25; Zhongshan, China).

\section{Availability of data and materials}

The datasets used and/or analyzed during the current study are available from the corresponding author and the first author on reasonable request.

\section{Authors' contributions}

WZ, ZTX, MYT, YWW and CYZ conceived and designed the study, performed the experiment, collected, analyzed and interpreted the data, and revised the manuscript. WZ and CYZ wrote the manuscript. All authors read and approved the final manuscript. WZ and CYZ confirm the authenticity of all the raw data.

\section{Ethics approval and consent to participate}

No applicable.

\section{Patient consent for publication}

No applicable.

\section{Competing interests}

All authors declare that they have no competing interests. 


\section{References}

1. Ferlay J, Soerjomataram I, Dikshit R, Eser S, Mathers C, Rebelo M, Parkin DM, Forman D and Bray F: Cancer incidence and mortality worldwide: Sources, methods and major patterns in GLOBOCAN 2012. Int J Cancer 136: E359-E386, 2015.

2. Casamayor M, Morlock R, Maeda H and Ajani J. Targeted literature review of the global burden of gastric cancer. Ecancermedicalscience 12: 883, 2018.

3. Sui H, Lou A, Li Z and Yang J. Lidocaine inhibits growth, migration and invasion of gastric carcinoma cells by up-regulation of miR-145. BMC Cancer 19: 233, 2019.

4. Yang W, Cai J, Zhang H, Wang G and Jiang W. Effects of lidocaine and ropivacaine on gastric cancer cells through down-regulation of ERK1/2 phosphorylation in vitro. Anticancer Res 38: 6729-6735, 2018.

5. Ye L, Zhang Y, Chen YJ and Liu Q: Anti-tumor effects of lidocaine on human gastric cancer cells in vitro. Bratisl Lek Listy 120: 212-217, 2019.

6. Piegeler T, Votta-Velis EG, Bakhshi FR, Mao M, Carnegie G, Bonini MG, Schwartz DE, Borgeat A, Beck-Schimmer B and Minshall RD: Endothelial barrier protection by local anesthetics: Ropivacaine and lidocaine block tumor necrosis factor- $\alpha$-induced endothelial cell src activation. Anesthesiology 120: 1414-1428, 2014

7. Piegeler T, Votta-Velis EG, Liu G, Place AT, Schwartz DE, Beck-Schimmer B, Minshall RD and Borgeat A: Antimetastatic potential of amide-linked local anesthetics: Inhibition of lung adenocarcinoma cell migration and inflammatory src signaling independent of sodium channel blockade. Anesthesiology 117: 548-559, 2012.

8. Wall TP, Crowley PD, Sherwin A, Foley AG and Buggy DJ: Effects of lidocaine and src inhibition on metastasis in a murine model of breast cancer surgery. Cancers (Basel) 11: 1414, 2019.

9. Matsumoto K, Umitsu M, De Silva DM, Roy A and Bottaro DP Hepatocyte growth factor/MET in cancer progression and biomarker discovery. Cancer Sci 108: 296-307, 2017.

10. Han SU, Lee HY, Lee JH, Kim WH, Nam H, Kim H, Cho YK, Kim MW and Lee KU: Modulation of E-cadherin by hepatocyte growth factor induces aggressiveness of gastric carcinoma. Ann Surg 242: 676-683, 2005.

11. Lee KH, Choi EY, Hyun MS, Jang BI, Kim TN, Kim SW, Song SK, Kim JH and Kim JR: Hepatocyte growth factor/c-met signaling in regulating urokinase plasminogen activator in human stomach cancer: A potential therapeutic target for human stomach cancer. Korean J Intern Med 21: 20-27, 2006.

12. Park WS, Oh RR, Kim YS, Park JY, Shin MS, Lee HK, Lee SH, Yoo NJ and Lee JY: Absence of mutations in the kinase domain of the met gene and frequent expression of met and HGF/SF protein in primary gastric carcinomas. APMIS 108: 195-200, 2000.

13. Okamoto W, Okamoto I, Yoshida T, Okamoto K, Takezawa K, Hatashita E, Yamada Y, Kuwata K, Arao T, Yanagihara K, et al: Identification of c-src as a potential therapeutic target for gastric cancer and of MET activation as a cause of resistance to c-src inhibition. Mol Cancer Ther 9: 1188-1197, 2010.

14. Kuniyasu H, Yasui W, Kitadai Y, Yokozaki H, Ito $\mathrm{H}$ and Tahara E: Frequent amplification of the c-met gene in scirrhous type stomach cancer. Biochem Biophys Res Commun 189: 227-232, 1992

15. Nessling M, Solinas-Toldo S, Wilgenbus KK, Borchard F and Lichter P: Mapping of chromosomal imbalances in gastric adenocarcinoma revealed amplified protooncogenes MYCN, MET, WNT2, and ERBB2. Genes Chromosomes Cancer 23 307-316, 1998

16. Sakakura C, Mori T, Sakabe T, Ariyama Y, Shinomiya T, Date K, Hagiwara A, Yamaguchi T, Takahashi T, Nakamura Y, et al: Gains, losses, and amplifications of genomic materials in primary gastric cancers analyzed by comparative genomic hybridization. Genes Chromosomes Cancer 24: 299-305, 1999.

17. Irby RB and Yeatman TJ: Role of src expression and activation in human cancer. Oncogene 19: 5636-5642, 2000

18. Kim LC, Song L and Haura EB: Src kinases as therapeutic targets for cancer. Nat Rev Clin Oncol 6: 587-595, 2009.

19. Anestis A, Zoi I and Karamouzis MV: Current advances of targeting HGF/c-Met pathway in gastric cancer. Ann Transl Med 6: 247, 2018

20. Moosavi F, Giovannetti E, Saso L and Firuzi O: HGF/MET pathway aberrations as diagnostic, prognostic, and predictive biomarkers in human cancers. Crit Rev Clin Lab Sci 56: 533-566, 2019.

21. Summy JM and Gallick GE: Src family kinases in tumor progression and metastasis. Cancer Metastasis Rev 22: 337-358, 2003.
22. Yan H, Sun Y, Wu Q, Wu Z, Hu M, Sun Y, Liu Y, Ma Z, Liu S, Xiao W, et al: PELP1 suppression inhibits gastric cancer through downregulation of c-Src-PI3K-ERK pathway. Front Oncol 9: $1423,2019$.

23. Kim HJ, Kang SK, Kwon WS, Kim TS, Jeong I, Jeung HC, Kragh M, Horak ID, Chung HC and Rha SY: Forty-nine gastric cancer cell lines with integrative genomic profiling for development of c-MET inhibitor. Int J Cancer 143: 151-159, 2018.

24. Huang KH, Sung IC, Fang WL, Chi CW, Yeh TS, Lee HC, Yin PH, Li AF, Wu CW, Shyr YM and Yang MH: Correlation between HGF/c-Met and notch1 signaling pathways in human gastric cancer cells. Oncol Rep 40: 294-302, 2018.

25. Oh HA, Lee G, Kang HJ, Kim YG, Bae SH, Lee JL, Lee KH, Hyun MS and Kim DS: Overexpression of c-met protein in gastric cancer and role of UPAR as a therapeutic target. Cancer Res Treat 35: 9-15, 2003.

26. Chen C, Tang X, Liu Y, Zhu J and Liu J: Induction/reversal of drug resistance in gastric cancer by non-coding RNAs (Review). Int J Oncol 54: 1511-1524, 2019.

27. Kiriyama S, Oda I, Nishimoto F, Mashimo Y, Ikehara $\mathrm{H}$ and Gotoda T: Pilot study to assess the safety of local lidocaine injections during endoscopic submucosal dissection for early gastric cancer. Gastric Cancer 12: 142-147, 2009.

28. Kim TH, Kang H, Choi YS, Park JM, Chi KC, Shin HY and Hong JH: Pre- and intraoperative lidocaine injection for preemptive analgesics in laparoscopic gastrectomy: A prospective, randomized, double-blind, placebo-controlled study. J Laparoendosc Adv Surg Tech A 23: 663-668, 2013.

29. Yao L, Zhang D, Zhao X, Sun B, Liu Y, Gu Q, Zhang Y, Zhao X, Che N, Zheng Y, et al: Dickkopf-1-Promoted vasculogenic mimicry in non-small cell lung cancer is associated with EMT and development of a cancer stem-like cell phenotype. J Cell Mol Med 20: 1673-1685, 2016

30. Acloque H, Adams MS, Fishwick K, Bronner-Fraser M and Nieto MA: Epithelial-mesenchymal transitions: The importance of changing cell state in development and disease. J Clin Invest 119: 1438-1449, 2009.

31. Toiyama Y, Yasuda H, Saigusa S, Matushita K, FujikawaH,Tanaka K, Mohri Y, Inoue Y, Goel A and Kusunoki M: Co-Expression of hepatocyte growth factor and c-met predicts peritoneal dissemination established by autocrine hepatocyte growth factor/c-met signaling in gastric cancer. Int J Cancer 130: 2912-2921, 2012.

32. Lee JC, Koh SA, Lee KH and Kim JR: BAG3 contributes to HGF-mediated cell proliferation, migration, and invasion via the egrl pathway in gastric cancer. Tumori 105: 63-75, 2019.

33. Koh SA and Lee KH: HGF-Mediated S100A11 overexpression enhances proliferation and invasion of gastric cancer. Am J Transl Res 10: 3385-3394, 2018.

34. Konturek PC, Konturek SJ, Sulekova Z, Meixner H, Bielanski W, Starzynska T, Karczewska E, Marlicz K, Stachura J and Hahn EG: Expression of hepatocyte growth factor, transforming growth factor alpha, apoptosis related proteins bax and bcl-2, and gastrin in human gastric cancer. Aliment Pharmacol Ther 15: 989-999, 2001.

35. Kamiya Y, Ohta K and Kaneko Y: Lidocaine-induced apoptosis and necrosis in U937 cells depending on its dosage. Biomed Res 26: 231-239, 2005.

36. Qu X, Yang L, Shi Q, Wang X, Wang D and Wu G: Lidocaine inhibits proliferation and induces apoptosis in colorectal cancer cells by upregulating mir-520a-3p and targeting EGFR. Pathol Res Pract 214: 1974-1979, 2018.

37. Zhu J and Han S: Lidocaine inhibits cervical cancer cell proliferation and induces cell apoptosis by modulating the IncRNA-MEG3/miR-421/BTG1 pathway. Am J Transl Res 11: 5404-5416, 2019.

38. Arnold L, Enders J and Thomas SM: Activated HGF-c-met axis in head and neck cancer. Cancers (Basel) 9: 169, 2017.

39. Rucki AA, Xiao Q, Muth S, Chen J, Che X, Kleponis J, Sharma R, Anders RA, Jaffee EM and Zheng L: Dual inhibition of hedgehog and c-met pathways for pancreatic cancer treatment. Mol Cancer Ther 16: 2399-2409, 2017

40. Leonetti E, Gesualdi L, Scheri KC, Dinicola S, Fattore L, Masiello MG, Cucina A, Mancini R, Bizzarri M, Ricci G and Catizone A: C-Src recruitment is involved in c-MET-mediated malignant behaviour of NT2D1 non-seminoma cells. Int J Mol Sci 20: 320, 2019. 